\title{
THE GASTRO PROTECTIVE EFFECT OF TRIGONELLA FOENUM GRAECUM SEED (METHI) AND OMEPRAZOLE IN EXPERIMENTALLY INDUCED GASTRIC ULCER IN RATS
}

\author{
AFROZ R ${ }^{1}$, RAHMAN KA ${ }^{2}$, KAMAL AHMM $^{3}$, LOTUS MA ${ }^{4}$, YESMIN ${ }^{5}$, YEASMIN N ${ }^{6}$, RAHMAN KM $^{7}$
}

\begin{abstract}
Context: The gastric ulcer is a common gastrointestinal problem in Bangladesh. Gastric epithelium is under constant assault by a series of endogenous noxious factors, including $\mathrm{HCl}$, pepsinogen I pepsin, and bile salts. In addition, a steady flow of exogenous substances such as medications, alcohol, and bacteria encounter the gastric mucosa. A highly intricate biologic system is in place to provide defense from mucosal injury and to repair any injury that may occur. From the ancient time, various plants were used in traditional medicine with reputation as efficacious remedies. The incidence of duodenal ulcer disease has been declining dramatically for the past 30 years, but the incidence of gastric ulcers appears to be increasing as a result of the widespread use of NSAIDs and low-dose aspirin. The list of plant derived modern medicine is very long now. About $33 \%$ of the drugs produced in the developed countries are derived from plants. Trigonella foenumgraecum (Fenugreek, Methi) is a herbal medicine used in many parts of world. Preliminary study on animal showed that Trigonella foenum-graecum seed has significant gastro-protective effect. A study was carried out to see the gastro-protective effect of Trigonella foenum-graecum (Fenugreek, Methi) and omeprazole in ethanol induced gastric ulcer in an experimental rats.
\end{abstract}

Material and Methods: The present study was performed on 24 (twenty four) rats which were divided randomly into 4 groups each having 6 rats in the Pharmacology Department of Dhaka Medical college, Dhaka. The rats were aged between 8-10 weeks of both sexes and weighing between 180-200 gm. The study was carried out to demonstrate the gastro-protective effect of aqueous extract and ethanolic extract of Trigonella foenum-graecum seed and omeprazole on ethanol induced gastric ulcer in experimental rats.

Result : Pretreatment with aqueous extract and ethanolic of Trigonella foenum-graecum seed $(500 \mathrm{mg} / \mathrm{kg} /$ body wt) showed very significant prevention in ethanol induced gastric ulcer in number of lesion, lesion length, lesion breadth, lesion area and lesion index. This prevention was statistically very significant $(P<0.001)$. In this study there was no statistical significant difference was observed between aqueous and ethanolic extracts of Trigonella foenumgraecum seed in gastro-protective effects.

Conclusion: The aqueous and ethanol extracts of Trigonella foenum-graecum seed and omeprazole possess gastro protective properties.

Key words: Gastro-protective, Trigonella foenum graecum seed (Methi) extract, omeprazole. J Dhaka Med Coll. 2017; 26(2) : 126-131

\section{Introduction:}

Bangladesh is a developing country with a very high point prevalence of duodenal ulcer disease $(11.9 \%)$ and $\mathrm{H}$. pylori prevalence of more than $90 \%$ in asymptomatic adults and $80 \%$ in children at the age of 5 years ${ }^{1}$. The gastric epithelium is under constant assault by a series of endogenous noxious factors, including $\mathrm{HCl}$, pepsinogen/pepsin, and bile salts. In addition, a steady flow of exogenous substances such as

1. Dr. Rumana Afroz, Assistant Professor, Department of Pharmacology, Dhaka Medical College, Dhaka.

2. Dr. Kazi Afzalur Rahman, Associate Professor, Department of Pharmacology, Dhaka Medical College, Dhaka.

3. Dr. A.H.M. Mostafa Kamal, Associate Professor, Department of Anatomy. Dhaka Medical College, Dhaka.

4. Dr. Mahbuba Jahan Lotus, Lecturer, Department of Pharmacology. Dhaka Medical College, Dhaka.

5. Dr. Sultana Yesmin, Assistant Professor, Department of Pharmacology. Dhaka Medical College, Dhaka

6. Dr. Nahid Yeasmin, Assistant Professor, Department of Physiology, Dhaka Medical College, Dhaka

7. Dr. Kazi Monisur Rahman, Assistant Professor, Gastroenterology, BSMMU, Dhaka

Correspondence :Dr. Rumana Afroz, Assistant Professor, Department of Pharmacology, Dhaka Medical College, Dhaka, Cell Phone: +8801712027705, E-mail: rumana.k54@gmail.com

Received: 21 July 2017 Revision: 01 August 2017

DOI: http://dx.doi.org/10.3329/jdmc.v26i2.38828 
medications, alcohol, and bacteria encounter the gastric mucosa. A highly intricate biologic system is in place to provide defense from mucosal injury and to repair any injury that may occur. The mucosal defense system can be envisioned as a three-level barrier, composed of pre epithelial, epithelial, and sub-epithelial elements $^{2}$. Peptic ulcer is a break in the gastric or duodenal mucosa that arises when the normal mucosal defensive factors are impaired or are overwhelmed by aggressive luminal factors such as acid and pepsin. The ulcers extend through the muscularis mucosae and are usually over $5 \mathrm{~mm}$ in diameter ${ }^{3}$.

The pharmacology of several agents that enhance the healing of peptic ulcers may be divided into three categories: (1) acidantisecretory agents: a) $\mathrm{H} 2$ receptor antagonist drugs (Ranitidine, Famotidine, Cimitidine), b) Antimuscarinic agents (pirenzepine, telenzepine ), c) proton pump inhibitors (Omeprazole, Pantoprazole, Lansoprazole, Rabeprazole) (2) mucosal protective agents- carbenoxolone sodium,sucralfate and prostaglandin analogues (3) agents that promote healing through eradication of $\mathrm{H}$ pylori.

Medicinal plants constitute an important natural wealth of a country. They play a significant role in providing primary health care service to rural people. According to WHO, herbal medicine, composed mainly of medicinal plants, are still curing diseases of an estimated 3.5 billion of the world's population as they can't afford western pharmacological drugs ${ }^{4}$. The Trigonella foenum graecum seed (Methi) is a very interesting one, for its pharmaceutical, industrial and alimentary valences.

Herbs play a far great part in our everyday lives than most of us realize. All herbals build on earlier knowledge, while reflecting the practice and interests of the time. The gastro-protective, cytoprotective and anti-ulcer effect of several other plants like Azadirachta indica (Neem), Ejambolana, Propolis ethanol extract, popular spice Anise-pimpinella anisum etc. are also studied by several other investigator ${ }^{5,6}$. They concluded that these plants possesses significant cytoprotective and anti-ulcer activities against experimentally induced gastric lesions possibly through promotion of mucosal defensive factors and anti-secretory or antioxidant status and decreasing lipid per oxidation.

Trigonella foenum-graecum (Fenugreek, Methi) is an herbaceous annual of $10-40 \mathrm{cfl}$, aromatic and has compound leaves of 7 to $12 \mathrm{~cm}$ long. It is a herbal medicine used in many parts of world. Its leaves are used for their cooling properties and its seed for their carminative, tonic and aphrodisiac effects ${ }^{6}$. The seed contains alkaloids, steroidal sapogenins, fixed oil and mucilage ${ }^{7}$. It has been used for labor induction, aiding digestion and lactation ${ }^{8}$. Preliminary study on animal showed that Trigonella foenum-graecum seed reduced total acid and showed significant ulcer protective effects in ethanol-induced ulcer model ${ }^{9}$. Other studies reveal the possible hypoglycemic and antihyperlipidemic properties of Trigonella foenum-graecum seed in animals ${ }^{8}$.

\section{Materials and Methods:}

The present study was performed on 24 (twenty four) rats which were divided randomly into 4 groups each having 6 rats. Groups were labeled as group-A, group-B, group-C and group-D. The rats were aged between 8-10 weeks of both sexes and weighing between 180-200 gm. They were kept for some days to acclimatize to the animal room conditions in medium sized metallic cages in the animal house of Pharmacology Department in Dhaka Medical college, Dhaka. They were allowed to live at room temperature' fed on standard pellets of rat food and allowed to drink water adlibitum.

\section{Materials:}

Aqueous and ethanolic extract of $T$. foenumgraecum seed

Omeprazole powder (Omenix suspensionIncepta pharmaceuticals Ltd.)

Absolute ethanol (99.9\%)

Distilled water (vehicle)

Normal rat food

Grouping of the animals :

Group A : This group was served as control Group for extract treated groups and they were provided with $1 \mathrm{ml}$ of distilled water $(5 \mathrm{ml} / \mathrm{kg}$ body wt) orally by gastric tube. 
Group B: They were provided with aqueous extract of $T$. foenum-graecum seed $(500 \mathrm{mg} / \mathrm{kg}$ body wt) orally by gastric tube.

Group C: They were provided with ethanolic extract of $T$. foenum-graecum seed $(500 \mathrm{mg} / \mathrm{kg}$ body wt) orally by gastric tube.

Group D: They were provided with Omeprazole suspension (20mglkg body wt) orally by gastric tube.

After 50 minutes of pretreated rats, $1 \mathrm{ml}$ of absolute ethanol $(5 \mathrm{ml} / \mathrm{kg}$ body wt.) was orally administered to all groups by gastric intubations. After 60 mins of administration of absolute ethanol all rats were sacrificed by an overdose of diethyl ether and were prepared for dissection. Then determination of formation of ulcer, lesion number, lesion length, lesion breadth, lesion area, lesion index were calculated. The study was carried out to demonstrate the effect of pretreatment with aqueous extract and ethanolic extract of $T$. foenum-graecum seed and omeprazole on ethanol induced gastric ulcer in experimental rats. The study was prospective experimental type and was conducted in the Department of Pharmacology, Dhaka Medical College, Dhaka, from July 2008 to June 2009. All the data were analyzed by SPSS version 16.1.

\section{Ethical Clearance :}

This study was approved by the Ethical Review Committee of Dhaka Medical College, Dhaka.

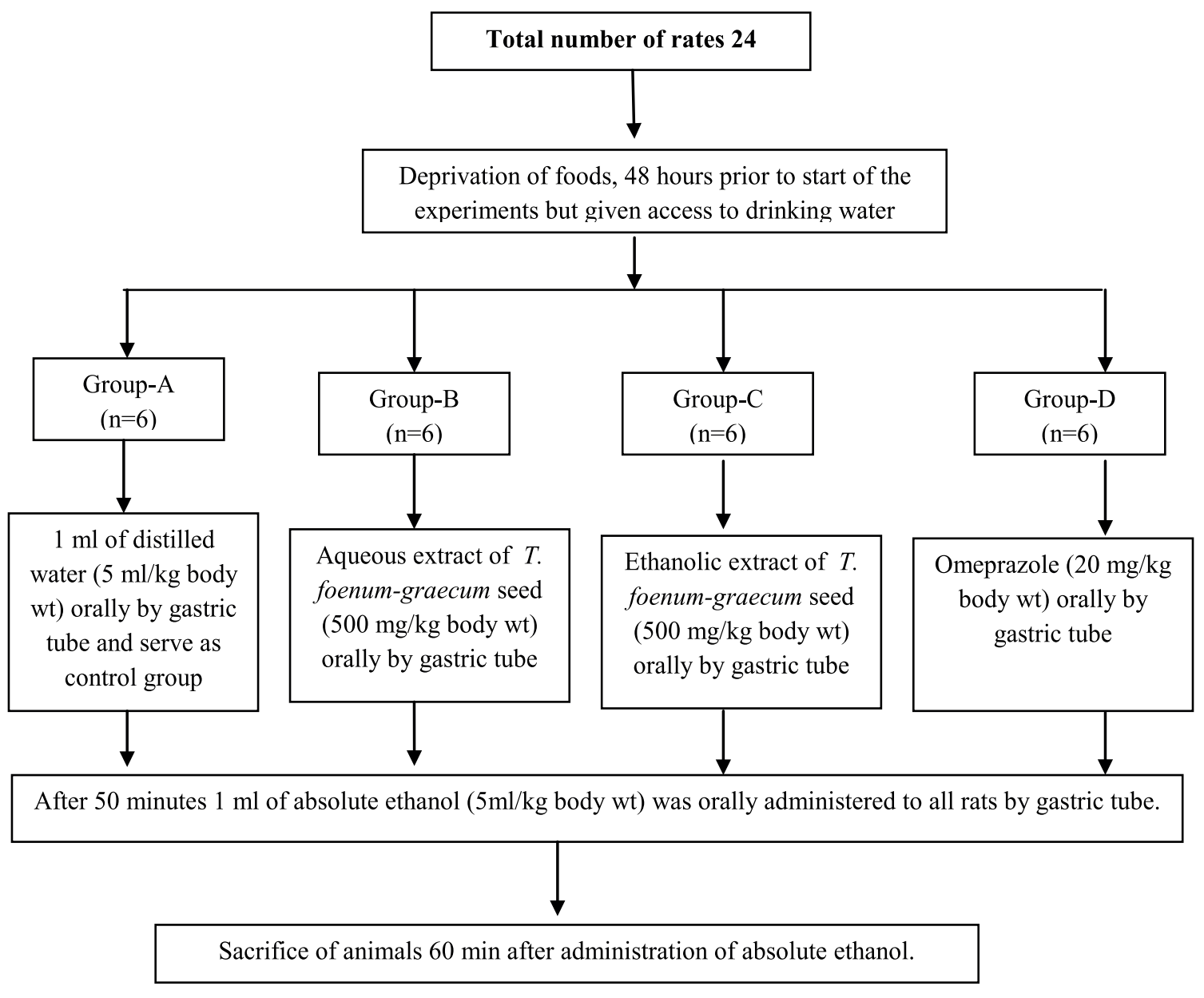

Figure-1 : Outline of the study 


\section{Results:}

The mean $( \pm \mathrm{SD})$ number of lesions (table-I) in group-A, group-B, group-C and group-D were $5.33 \pm 0.82,3.50 \pm 0.55,4.17 \pm 0.75,4.33 \pm 1.03$ respectively. Statistically highly significant of difference were observed between the experimental group and the control group $(\mathrm{P}<0.001)$. The mean lesions length (Mean $\pm \mathrm{SD})$ in group-A, group-B, group-C and group-D were $6.75 \pm 3.71,2.42 \pm 1.63,3.48 \pm 2.25$ and 2.38 \pm 1.84 respectively. The mean lesions breadth (Mean $\pm \mathrm{SD}$ ) in group-A, group-B, group-C and group-D were $1.63 \pm 1.29,0.62 \pm 10.67,0.77$ \pm 0.48 and $0.64 \pm 0.66 \mathrm{~mm}$ respectively.

The area mean of lesions in group-A, group-B, group-C and group-D were $13.66 \mathrm{~mm}^{2}$,
$2.32 \pm 2.93 \mathrm{~mm}^{2}, 3.30 \pm 3.55 \mathrm{~mm}^{2}$ and $2.58 \pm 5.26$ $\mathrm{mm}^{2}$ respectively (table-I). Statistically highly significant of difference were observed between the experimental groups and the control group $(\mathrm{P}<0.001)$. The mean lesions index in group- $\mathrm{A}$, group-B, group-C and group-D were $36.00 \pm 11.08,8.08 \pm 2.77,14.51 \pm 2.47$ and $9.91 \pm 2.82$ respectively. Statistically highly significant of difference were observed between the experimental groups and the control group $(\mathrm{P}<0.001)$.

The percent Inhibition (table-I, Fig-2) in group$\mathrm{B}$, group-C and group-D were $77.56 \%, 59.69 \%$ and $72.47 \%$ respectively. The highest percentage inhibition occurred in group-B followed by group-D and then group-C (Fig-2) .

\section{Table -I}

Effect of pretreatment of aqueous and ethanolic extracts of $T$. foenum-graecum seed and omeprazole on changes in the stomach lesion.

\begin{tabular}{|c|c|c|c|c|c|c|}
\hline Groups & $\begin{array}{c}\text { Number of } \\
\text { lesion } \\
\text { (mean } \pm \mathrm{SD})\end{array}$ & $\begin{array}{c}\text { Lesion } \\
\text { length in } \mathrm{mm} \\
\text { (mean } \pm \mathrm{SD})\end{array}$ & $\begin{array}{c}\text { Lesion } \\
\text { breadth in } \mathrm{mm} \\
(\text { mean } \pm \mathrm{SD})\end{array}$ & $\begin{array}{c}\text { Lesion area } \\
\text { mm2 } \\
(\text { mean } \pm \mathrm{SD})\end{array}$ & $\begin{array}{r}\text { Lesion index } \\
(\text { mean } \pm \mathrm{SD})\end{array}$ & $\begin{array}{c}\% \text { of } \\
\text { inhibition }\end{array}$ \\
\hline Group A $(n=6)$ & $5.33 \pm 0.82$ & $6.75 \pm 3.71$ & $1.63 \pm 1.29$ & $13.66 \pm 15.14$ & $36.00 \pm 11.08$ & \\
\hline Group B $(n=6)$ & $3.50 \pm 0.55^{* *}$ & $2.42 \pm 1.63 * *$ & $0.62 \pm 0.67 * *$ & $2.32 \pm 2.92^{* *}$ & $8.08 \pm 2.77^{* *}$ & $77.56 \%$ \\
\hline Group C $(n=6)$ & $4.17 \pm 0.75^{* *}$ & $3.48 \pm 2.25^{* *}$ & $0.77 \pm 0.48^{* *}$ & $3.30 \pm 3.55^{* *}$ & $14.51 \pm 2.47^{* *}$ & $59.69 \%$ \\
\hline Group D $(n=6)$ & $4.33 \pm 1.03 * *$ & $2.38 \pm 1.48^{* *}$ & $0.64 \pm 0.65^{* *}$ & $2.57 \pm 5.26^{* *}$ & $9.91 \pm 2.82^{* *}$ & $72.47 \%$ \\
\hline
\end{tabular}

Comparison between Group-A (Control) and other groups (Group-B, Group-C and Group-D) are done by unpaired student's ' $\mathrm{t}$ ' test. ** very significant $(\mathrm{P}<0.001)$

Group A : This group was served as control group for extract treated groups and they were provided with 1 $\mathrm{ml}$ of distilled water $(5 \mathrm{ml} / \mathrm{kg}$ body $\mathrm{wt}$ ) orally by gastric tube.

Group B: They were provided with aqueous extract of $T$. foenum-graecum seed (500mg/kg body wt) orally by gastric tube.

Group C: They were provided with ethanolic extract of $T$. foenum-graecum seed $(500 \mathrm{mg} / \mathrm{kg}$ body wt) orally by gastric tube.

Group D: They were provided with Omeprazole suspension (20mglkg body wt) orally by gastric tube.

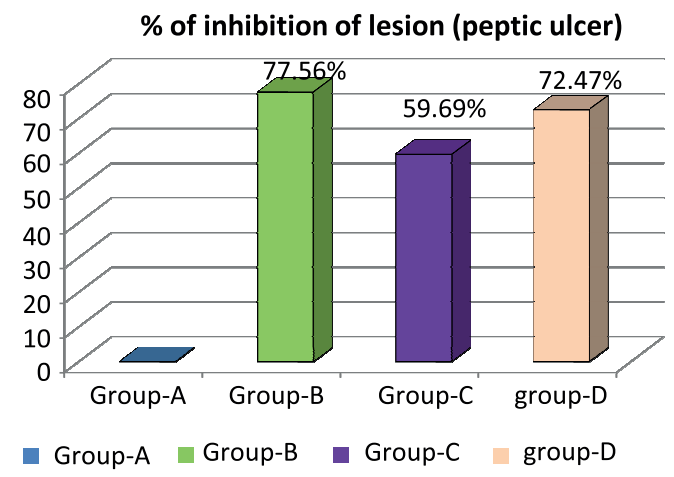

Fig.-2 : Effect of pretreatment of aqueous and ethanolic extracts of $T$. foenum-graecum seed and omeprazole on \% inhibition of lesion in ethanol treated rat's stomach.

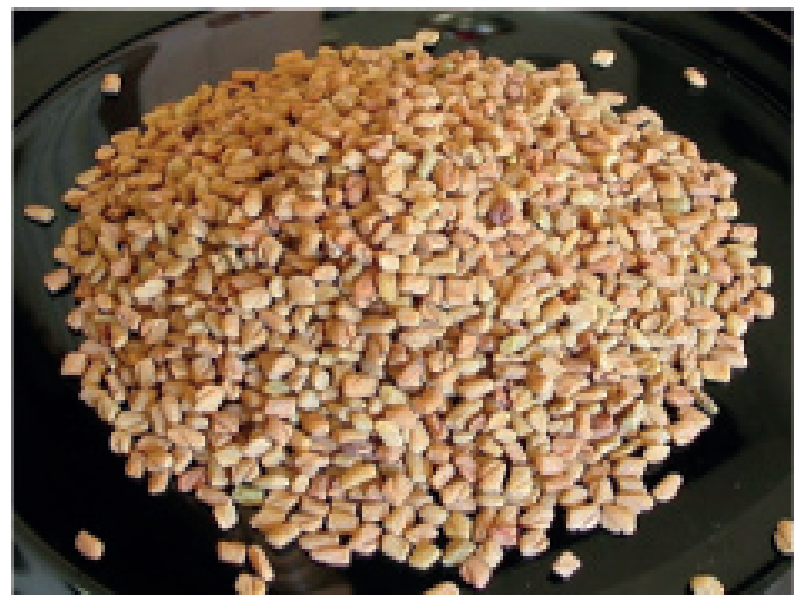

Fig.-3 : Fenugreek Seed (Methi) 


\section{Discussion}

The present study was carried out to evaluate the gastro-protective effect of Trigonella foenum graecum seed (Methi) seed on experimentally induced gastric-ulcer in rats. For this purpose, effect of aqueous and ethanolic extract of Trigonella foenum graecum seed (Methi) seed were demonstrated both in normal untreated and ethanol induced gastric damage in rats. The seed have been used to treat a number of gastrointestinal disorder ${ }^{9}$. Although Trigonella foenum graecum seed (Methi) seed has not been well established in promoting protection toward gastric mucosa, many properties of Trigonella foenum graecum seed (Methi) seed as in antioxidant properties ${ }^{10}$ anti-inflammation ${ }^{11}$ and wound healing ${ }^{12}$ can be applied in elucidating the mode of protection produced by Trigonella foenum graecum seed (Methi) seed. In the present study, Absolute ethanol was used as agent to induce stomach ulcer in rats. The dose and routes of administration was selected according to Mequanente et al (2006) ${ }^{13}$ and Mahmood et $\mathrm{al}^{14}$ (2005).

The mean $( \pm \mathrm{SD})$ number of lesion in group-A and group-C were $5.33 \pm 0.82$ and $4.17 \pm 0.75$ respectively. Statistically highly significant of difference were observed between the groups $(\mathrm{P}<0.01)$. The mean $( \pm \mathrm{SD})$ number of lesion in Group-B and group-D were $3.50 \pm 0.55$ and $4.33 \pm 1.33$ respectively. The mean $( \pm \mathrm{SD})$ number of lesion in group $\mathrm{C}$ and group $\mathrm{D}$ were $4.17 \pm 0.75$ and $4.33 \pm 1.33$ respectively. Pandian et $\mathrm{al}^{9}$ (2002) studied the effect of Trigonella foenum graecum seed (Methi) seed compared to omeprazole on ethanol-induced gastric ulcer. The aqueous extract and a gel fraction isolated from the seed showed significant ulcer protective effects. Their observations concluded that Trigonella foenum graecum seed (Methi) seed possess anti- ulcer potential.

The experiment also showed (table-I, Fig-2) that the highest percent inhibition occurred in group-B (pretreated with aqueous extracts of Trigonella foenum graecum seed) followed by group-D (pretreated with omeprazole powder $20 \mathrm{mg} / \mathrm{kg}$ body wt) and then group-C (pretreated with ethanolic extract of Trigonella foenum graecum seed). In 2005 in a study Mahmood et al. investigated the gastric protective effect of honey in combination with aqueous and ethanolic extract of Trigonella foenum graecum seed (Methi) in rats against ethanol-induced gastric damage that revealed that honey in combination with aqueous seed extract was significantly more effective than honey alone or in combination with alcoholic extract in preventing gastric lesions formation $^{14}$. Their observations showed that Trigonella foenum graecum aqueous seed extract posse's gastro-protective potential.

Although Trigonella foenum graecum seed (Methi) has not been well established in promoting protection toward gastric mucosa, many properties of Trigonella foenum graecum seed with its anti-inflammatory, anti-oxidant and in wound healing can be applied in elucidating the mode of protection produced by Trigonella foenum graecum seed (Methi) in this study. The aqueous extracts of Trigonella foenum graecum seed (Methi) in this study then the ethanolic extract of Trigonella foenum graecum seed (Methi) significantly inhibited the action of ethanol in inducing ulcer. The gastroprotective effect is statistically significant when compared to control group.

\section{Conclusion}

Aqueous and ethanol extracts of Trigonella foenum graecum seed (Methi) and omeprazole possess gastro protective properties. In this study there was no statistical significanct difference was observed between aqueous and ethanolic extracts of Trigonella foenum graecum seed (Methi) in gastro protective effects. Nevertheless, both extracts of $\mathrm{T}$ Trigonella foenum graecum seed (Methi) were able to deliver satisfying gastro protective effects in preventing gastric mucosal lesions formation induced by absolute ethanol. Further investigation of Trigonella foenum graecum seed (Methi) in inducing gastro protectiveness needs to be carried out because it might be beneficial in treating a variety of diseases that are related to gastric mucosal injury. 


\section{References:}

1. Ahmadiani A, Javan M, Semnanian S, Baratand EM. Kamalinejad. Anti-inflammatory and Anti-pyretic Effects of Trigonella foenum-graecum Leaves Extract in the Rates. J.Ethnopharmacol. 2001; 72: 283-88

2. Valle JD. Peptic ulcer disease and related disorders. In Harrison's Principles of Internal Medicine. Editors Kasper DL, Fauci AS, Longo DL, Braunwald E, Hauser SL, Jameson JL. $16^{\text {th }}$ edition. New York; 2005:1746-62.

3. Mc QKR. Alimentary Tract in Current Medical Diagnosis and Treatment. Editors Tierney Jr LM, Mc Phee SJ, Papadakis MA. $46^{\text {th }}$ edition, International edition. McGraw-Hill. New York ; 2007: 554-663.

4. Ghai A. Medicinal Plants of Bangladesh. $2^{\text {nd }}$ edition, Dhaka. Asiatric Society of Bangladesh;2003: 1-35.

5. Liu $\mathrm{CF}$, Lin $\mathrm{CC}$, Lin $\mathrm{MH}$, Lin YS, Lin $\mathrm{SC}$. Cytoprotection by Propolisethanol Extract of Acute Absolute Ethanol-induced Gastric Mucosal Lesions. Am J Chin Med. 2002 ; 30(2-3):245-54.

6. Al MA, Alhaider AA, Mossa JS, Al-Sohaibani MO, Rafatullahs. Aqueous Suspension of Anise "Pimpinellaanisum" Protect Against Chemically Induced Gastric Ulcers. World $J$ Gastroentero. 2007;13(7):1112-18.

7. Chopra RN, Hondaand LD, Kapur. Chapra's Indigenous Drugs of India. Academic Publishers. Calcutta, New Delhi, India;1982: 582
8. Evans WC. Trease and Evans Pharmacognosy. $5^{\text {th }}$ edition WB Saunders, London;2000:188.

9. Pandian RS, Anuradha CV, Viswanathan P. Gastroprotective Effect of fenugreek seed (Trigonella foenum graecum) on Experimental Gastric Ulcer in Rats. J Ethnopharmacol. 2002;81(3):393-97.

10. Basch E, Kuo G, Smith M. Therapeutic Applications of fenugreek. Altern Med Rev. 2003;8: 20-28.

11. Anuradha CV and Ravikumar P. Anti-lipid per Oxidative Activity of Seed of Fenugreek (Trigonella foenum graecum). Medical Science Research.1998; $26: 317-21$

12. Mustafa MR, Mahmood AA, Salmah I. Effects of Trigonella foenum-graecum Seed Extract in Combination with Honey on Experimental Wound Healing in Rats. International Journal of Molecular Medicine and Advance Science. 2005; 1(1):29-33.

13. Mequanente S, Makonnen E, Asfaw DA. Gastroprotective Effect of Aqueous trigonella feonum-gracum and linumussitatissimum Seed Extracts in Mice. Pharmacology online. 2006 ; 2 : 324-34.

14. Mahmood AA, Sidik KS. Anti-ulcer and Gastroprotective Effects of Honey in Combination with Trigonella foenum graecum Seed Extract on Experimental Gastric Ulcer in Rats. International Journal of Molecular Medicine and Advance Science. $2005 ; 1(3): 225-9$. 